\title{
LIBRARIES REBRANDING AND REPOSITIONING: WHAT CAN INDONESIAN LIBRARIANS LEARN FROM THE POPULARITY OF ONLINE MOTORCYCLE TAXI (OJEK)?
}

\author{
Nuning KURNIASIH \\ Universitas Padjadjaran, nuning.kurniasih@unpad.ac.id \\ Proceedings \\ The 2016 International Conference on Media: Mass Media at Crossroads Conference 2016 \\ Universitas Padjadjaran, Bandung December 6, 2016
}

Page: $481-488$

\begin{abstract}
Even though library and librarian undergo better changes, the perception and stereotype towards library and librarian has not changed much. It is shown by the perception and stereotype of the librarian themselves towards the profession of librarian. From another side, the management of online motorcycle taxi has succeeded in rebranding and repositioning motorcycle taxi and the drivers, thus it gains more positive image in the society. There are some values added given eventually changes perception towards motorcycle taxi and the drivers. This study attempts to explore how librarians employ image rebranding and image repositioning in order to gain more positive image for the library as it done to the online motorcycle taxi company. The research method used is descriptive qualitative. The techniques used to collect data is Focus Group Discussion (FGD) with 39 librarians in Banten - Indonesia, interview, observation and literature review. The results showed (1) amongst the librarians, a librarian still has a conservative image. (2) There are some points on why people prefer online motorcycle taxi rather than conventional one, i.e. company reputation, quality services, fixed tariff, choices of payment method (cash and non cash), easy to order, safety, comfort, all in one services, velocity, safety driving and services (3) as for library, rebranding emphasizes the changes of values offered for the users thus they can be loyal, and improving the organization culture in order to achieve rebranding goals. In other hand, repositioning serves as an attempt to accommodate the development of society characteristics and information technology advancement. Library has to accommodate the expectation of both digital native and digital immigrant simultaneously. Library rebranding and repositioning expected to be able to improve the positive image of library and also the librarian .
\end{abstract}

Keyword: Rebranding, Repositioning, Library Image, Librarian Image, Perception

\section{INTRODUCTION}

The concept of librarians' image is built upon public's perception or impression towards the library. Arant and Benefield (2002) argue that librarians' image changing over time. The old literatures mentioned the image of librarians including their personal traits, such as accessible, friendly, skilled, not-a-club-night-person, tactful, patient, also posses a great curiosity of sciences. Besides, librarians have the stereotype as scholarly, resourceful, professional, timid, plain-looking and 
passive gatekeeper (Arant \& Benefiel, 2002, p. 21). Some authors called librarian as indispensable helper while the others called librarian as people who only care about books (Arant \& Benefiel, 2002 , p. 21). On the other hand, Kneale (2002) suggests the perception towards librarian has not changed since medieval, which librarian considered as geeky, nerdy, and unfashionable. Calvert (2014) points out some cartoons of librarian where librarian frequently depicted as an obstinate person who refuses to adopt new technology or in other words outdated.

Indonesian also has the same peception regarding librarian, where it is considered as not prestigious profession. In some cases, the problematic employees are assigned in the library. It triggered reaction from the librarians, shown by the emergence of Facebook group named "Librarian Solidarity to Refuse the Assignment of Problematic Employees in the Library". It is difficult for librarians to represent the image of librarian profession as an information expert, who always provides information solution for the clients, an expert people refer to in finding actual, relevant, and accurate information. Thus, librarians need to improve their image more positively. Librarians image affects the library image, vice versa.

Since 2015, online motorcycle taxi service has been improving a lot in Indonesia. This online service was first established by a company named "Go-Jek". Since its launched, Go-Jek has gained popularity. Online motorcycle taxi then developing massively, shown by the emergence of Go-Jek's competitor, such as Grab, Uber, Ladyjek, Teknojek, Topjek, Blujek, Ojek Argo, Ojek Kampung, etc. There has been conflict of interest between online motorcycle taxi and conventional motorcycle taxi, where online motorcycle taxi regarded as a threat for the conventional ones. Meanwhile, people prefer online motorcycle taxi more than conventional one. Online motorcycle taxi users include students, housewifes, office employees, artist, also government official. Online motorcycle taxi has expanded its services by providing food delivery services, goods delivery services, shopping services, massage delivery services, cleaning services, beauty services, mobile-ticketing services, and provide events information, drugs selling services, and car maintenance services, along with easy payment process.

Motorcycle taxi is indeed different with library. Nevertheless, I see some points can be learned from the growth of online motorcycle taxi, such as how people use the services enthusiastically, how GoJek becomes the most wanted transportation tools for everyone, and how this online service has won over the conventional one. In this case, I assume the management of online motorcycle taxi has succeeded in rebranding and repositioning motorcycle taxi and the drivers, thus it gains more positive image in the society.

Bouchet (2000) suggests an institution management is built upon three significant points, i.e. (1) the institution image, in which how the institution is perceived by public affected by goodwill, reputation, and rumours; (2) the institution identity, including how the institution identity can be represented by its brand, logo, advertising, employee politics, building, etc. and how it is delivered to the public; (3) clear and implicit organization culture, which based on the strong and firm foundation.

According to American Marketing Association, brand is a name, the term for design, symbols, or other features identifying the difference of goods or services from other competitors. Meanwhile, branding is the process to create the differences, which shown by the value offered (Keller, 2013). It is also applied for library where rebranding library does not only the matter of changing logo or other identities, but also emphasized on the changing of value offered to the users, so they can be loyal. Managing brand is the matter of having attraction, utilizing image, inspiring trust, generating 
acknowledgment, making differences and achieving advancement (Bouchet, 2000). Library needs to reconstruct the values will be delivered, then arranging rebranding strategies.

On the other hand, library repositioning needed to enable library to identify its target market, mainly relate to the digital society changes nowadays; realizing its position and its differences with other libraries or information centers. Brand positioning employed to achieve brand's competitive superiority before the consumer and repositioning employed in order to create new position for the brand's image in the presence of consumer (Keller, 2013).

This study attempts to explore how librarians employ image rebranding and image repositioning in order to gain more positive image for the library by answering these research questions: (1) how do the librarians perceive the profession of librarian?; (2) what is librarians respond regarding the conventional and online motorcycle taxi?; (3) how do librarians employ image rebranding and repositioning to gain more positive image for the library?

\section{RESEARCH METHOD}

The method used is descriptive qualitative. Elliot argue that qualitative research based upon the choice of limitless description, utilizing particular strategies to improve the design and analysis credibility, applying open question technique, defining particular strategies to apprehend the right phenomenon, also defining success condition of something new (Elliot and Timulak, 2005). Descriptive qualitative research aims to describe a phenomenon more detail, seeking for elaboration of differences or developing a phenomenon theory using empiric analysis.

The technique used to collect data is Focus Group Discussion (FGD) with 39 librarians in Banten, Indonesia, including city library, university library, and schools library; interview; observation and literature review. FGD was conducted during the event "Public Speaking Workshop for Librarians" which held by Public Library of Banten Province in April 2016. I gave lecture with the subject "Public Relations in Library" and conducted interactive discussion, which including how the library and librarians can derive some lessons learn from the image branding and positioning of online motorcycle taxi.

Qualitative data analysis combining basic approach and details, from a mere of viewpoints, attention to the conclusion, up to elaborating categories, hermeneutic interpretation or identifying structures, which aim to generalize by comparing various materials, texts, and cases (Flick, 2013, p. 5).

\section{RESULT AND DISSCUSSION}

\section{Librarians Perception Regarding the Profession of Librarian}

In order to find out the librarians perception regarding their profession as librarian, I, hereby, attach some pictures from the internet.

Table 1

Librarians Perception towards Some Professions in the Picture

\begin{tabular}{|r|l|l|}
\hline No & \multicolumn{1}{|c|}{ Librarians Perception } \\
\hline 2 & $\begin{array}{l}\text { The FGD participants agreed this picture represents } \\
\text { the executives, bank employees, and flight attendants. } \\
\text { This perception refers to the outfit, bag, shoes, and the } \\
\text { style of people in the picture. }\end{array}$ \\
\hline $\begin{array}{l}\text { The FGD participants agreed the attributes shown in } \\
\text { the picture represent the profession of the man as a } \\
\text { doctor and the woman as a nurse. The main point is the }\end{array}$
\end{tabular}




\begin{tabular}{|c|c|c|}
\hline & $\begin{array}{l}\text { Image Source: } \\
\text { 1. } \quad \text { https://mysimpleprese } \\
\underline{\text { nttense.files.wordpress.com/ }} \\
\underline{2011 / 12 / \text { doctor3.gif }}\end{array}$ & $\begin{array}{l}\text { stethoscope worn by the man and the woman, and the } \\
\text { outfit also. }\end{array}$ \\
\hline 3 & $\begin{array}{l}\text { Image source: } 1 . \\
\text { http://caricaturecartoon.blogs } \\
\text { pot.co.id/2012/12/lecturer- } \\
\text { caricature-professor- } \\
\text { cartoon.html }\end{array}$ & $\begin{array}{l}\text { The FGD participants agreed these two pictures } \\
\text { represent a teacher or a lecturer. The main point of the } \\
\text { picture is the blackboard, papers, and the style. }\end{array}$ \\
\hline 4 & $\begin{array}{l}\text { Image Source: } \\
\text { 1. mugshot.com ; 2. @ } \\
\text { Charlie de Montagnac }\end{array}$ & $\begin{array}{l}\text { The FGD participants agreed these pictures represent } \\
\text { a librarian. The main point is the book pile, the } \\
\text { bookshelf, glasses, and the style. }\end{array}$ \\
\hline
\end{tabular}

The FGD participants then given a question "Which one of you in the room represents a librarian?", to which the participants answered by pointing out an old man with the glasses in the room. Then, I asked a participant in the room, a young and good-looking gentleman, to stand up and questioned the others in the room, "Is he a librarian?". To which the participants answered in unison that he is not a librarian, he did not look like a librarian, while in fact they do know he is a librarian.

In other words, even amongst the librarians, a librarian still has a conservative image. They do have stereotype that a librarian is physically an old man with glasses, not a good-looking young gentleman. It is still surprised them when they find a librarian opposites the stereotype, a librarian who is young, attractive, and trendy.

Kneale survey result (2004) shows how most of the respondents refer to an old lady with conservative style as a librarian, and when a picture of young lady shown to them as a librarian, they replied to it as too young to be a librarian. Not only in real life, the image of a librarian in movies also shown as a quiet old lady who is always doing conventional tasks, such as sitting behind a desk, holding a book or standing quietly at the stairs. The moviemakers still present the stereotype of librarian by showing it visually in the movie (Riggins, 2007). Tanisha R. Ford suggests one's style and clothes can present his professionalism and intellectual competences (Pagowsky \& Rigby, 2014). Keer and Carlos (2014) argue the effective way to overcome negative stereotype of librarian is by working diligently for the marginal society.

\section{Librarian Responds toward the Conventional and Online Motorcycle Taxi}

FGD result shows some differences between conventional and online motorcycle taxi, i.e. (1) the unstable fee of conventional motorcycle taxi enables bargaining while the fee of online motorcycle taxi is definite based on the mileage; (2) the payment method of conventional motorcycle taxi is only cash while online one enables other choices of payment method; (3) conventional one requires people to go to the drivers waiting point while online one enables people to get the services only by clicking the apps on their mobile; (4) conventional one is unorganized while the online one is 
organized, which giving safety to the clients; (5) the drivers for conventional one do not get training, while online drivers get safety and services training, to which giving clients comfort; (6) conventional one only drives people to the destination while online one provides other services such as food delivery, goods delivery, etc.; (7) conventional drivers spend their time waiting for clients while online drivers can do other services or job while waiting for the clients; (8) conventional drivers do not wear uniform and usually do not provide helmet for the clients, while online drivers always wearing uniform and provide helmet for the clients; (9) conventional one does not have consumer care while online one has it.

Therefore, there are some points on why people prefer online motorcycle taxi rather than conventional one, i.e. company reputation, quality services, fixed tariff, choices of payment method (cash and non cash), easy to order, safety, comfort, all in one services, velocity, safety driving and services. Those values added given eventually changes perception towards motorcycle taxi and the drivers. Motorcycle taxi clients improving significantly with vast market segmentation. Motorcycle taxi is no longer for the middle to lower class but also for the upper class. This service is most needed in the traffic condition. Some artists and government officials also use this service when facing traffic. People do not get embarrassed anymore when using motorcycle taxi, even some of them posting up a selfie while driving it. Some clients even utilize this online service to get food when they are too lazy to go out or traffic everywhere. Online motorcycle taxi establishes prime services because they know the clients' need really well, they pay attention to clients' needs, meet clients' expectation, accept negative and positive feedbacks and always improve their services. Peter Drucker argues that the quality of a product or service not based upon what is given but what the clients get (Wolff, 2012).

\section{Libraries Rebranding and Repositioning}

Some Indonesian librarians are quite well advanced, always up to date (including to adopt new technology), even some librarians are young and attractive, yet the stereotype of conventional librarian still lingers in the society's mind. Meanwhile, library users life gets more dynamic. They have some choices of information sources. Internet regarded as more complete and easy to access information source than the conventional library. More people access information sources on the free-internet than accessing digital library shown by the amount of internet users penetration than the visitors amount in the digital library. The characteristic of digital society, which needs fast and easy information, affects their expectation towards the library.

Considering the values added by the online motorcycle taxi, there are some plus points resulting in the popularity and successful of this service, and it successes in gaining most of the motorcycle taxi clients, even attract people who never use this service becomes clients of this service; the company image ensures the given services standard. The service standard includes definite time and fixed tariff, access speed and velocity, respond to the feedbacks, comfort, safety, and various services with trained and discipline drivers. In order to employ rebranding, Todor (2014) suggests improving the organization by reviewing the brand personality first. Brand personality means a set of personal characteristic associated with the brand (Aaker J.L., 1997; Sweeny \& Brandon, 2006). There are five brand personality dimensions, i.e. sincerity, excitement, competence, sophistication and ruggedness (Aaker J. L., 1997), while the significant points of online brand personality including sophistication, excitement, affection, popularity, and competence (Ozaki, 2006). In this case, library may collaborate both online and offline brand personality.

Library does not aim for popularity, but aim to encourage people to use all of its sources both online and offline as much as possible. Nevertheless, library utilization will not be optimal when it is 
unknown, or the services provided are unknown by people, or the services offered do not meet the client's expectation. As we know, there is stigma and perception in the society towards the library and by rebranding the stigma and perception expected to be more positive. Online motorcycle taxi success in changing the society perception towards motorcycle taxi and its drivers can be a good example for institution or company to employ rebranding and repositioning.

There are several stages to employ rebranding for the library by taking notes of the brand personality and the popularity and successful of online motorcycle taxi: (1) sincerity means how the library is able to provide sincere service, meet the client's expectation, understand the client characteristics, adapt with the surrounding change, show hospitality and kindness to the clients; (2) excitement requires library to always provide super services, full of spirit, motivation and up to date; (3) sophistication requires library to give attractive, safety, comfort and professional services; (4) ruggedness requires the librarians to be ready and strong in facing threats and challenges ahead; (5) affection requires the library to connect to other libraries or other information networks; (6) popularity, library need to be known by its competitive superiority and value added distinct it to the other libraries, and the librarians are dynamic personality. By reviewing these values, library can determine which dimensions to be improved in order to strength its competitive superiority.

Then, library can employ repositioning. Positioning is the part of brand identity and proposition values which actively communicated to the targeted market and demonstrating superiority through competed brands (Aaker D. A., 2002). Repositioning adapted to accommodate the environment changes, which can represent the fundamental changes of company or institution's value (Turner, 2003). There are six elements affecting the successful of repositioning strategy, that are core, deliberate strategic values, strategic flexibility and strong learning capabilities, high customer awareness and sensitivity, critical external orientation, top management commitment and belief in the product and brand (Ryan, Moroney, Geoghegan, \& Cunningham, 2007).

Online motorcycle taxi succeed in repositioning motorcycle taxi as transportation method for all, succeed in positioning motorcycle taxi as the most wanted transportation method nowadays not only as conventional method competitor, but also for the other method of transportations, which offer speed, safety, and comfort.

To employ repositioning, library required to analyze fundamental values offered to the users, flexible in serving but still based upon quality standard, understanding the targeted users, eager to learn and accept critics also commitment from the management to reposition the library. In this internet era, library does not only serve as an information provider, but also serve as digital literation ambassador, which able to guide the society in filtering true or false information, a meeting place for people to meet, interact, study, discuss, doing research, relaxing, and as provider for online reading materials by providing feature covered reader interaction online. Thus, library repositioning has to accommodate both digital immigrant and digital native segment.

\section{CONCLUSION}

Even though library and librarian undergo better changes, the perception and stereotype towards library and librarian has not changed much. It is shown by the perception and stereotype of the librarian themselves towards the profession of librarian, which regarded as conservative. Therefore, librarians need to present themselves more, present their works and the values offered to meet the user's expectation thus the users aware of the library and librarian changes. Online motorcycle taxi innovation can be regarded as a company succeeds in rebranding and repositioning the motorcycle taxi. As for library, rebranding emphasizes the changes of values offered for the users thus they can 
be loyal, and improving the organization culture in order to achieve rebranding goals. In other hand, repositioning serves as an attempt to accommodate the development of society characteristics and information technology advancement. Library has to accommodate the expectation of both digital native and digital immigrant simultaneously. Library rebranding and repositioning expected to be able to improve the positive image of library and also the librarian.

\section{REFERENCES}

Aaker, D. A. (2002). Building Strong Brands. London: Simon \& Schuster UK Ltd.

Aaker, J. L. (1997). Dimensions of Brand Personality. Journal of Marketing Research Vol.34 Issue 3, 347-356.

Afandi, R. (2015, July 9). Karya Sosial Di Balik Lahirnya Ojek Online. Retrieved from Lilin Inspirasi: $\quad$ http://www.lilininspirasi.com/2015/12/inspirasi-di-balik-lahirnya-ojekonline.html

American Marketing Association. (2016). Brand. Retrieved from AMA Dictionary: https://www.ama.org/resources/pages/dictionary.aspx?dLetter=B

Arant, W., \& Benefiel, C. R. (2002). The Image and Role of the Librarian. Binghamton, NY: Haworth Information Press.

Bouchet, D. (2000). What is "Corporate Image" and "Corporate Identity" - and why do people talk so much about it? Retrieved from sam.sdk.dk: http://www.sam.sdu.dk/ dom/priv/research/CorporateIdentity.pdf

Budiari, I. (2015, June 11). Go-Jek Drivers Fearing Violent Resistance from Traditional Ojek. Retrieved from The Jakarta Post: http://www.thejakartapost.com/news/2015/06/11/go-jekdrivers-fearing-violent-resistance-traditional-ojek.html

Calvert, S. (2014). Second Life Librarianship and the Gendered Work of Care in Technology. PhoenEx 9, no. 2 (fall/winter), 24-42.

Doucett, E. (2008). Creating Your Library Brand : Communicating Your Relevance and Value to Your Patrons . United States of America: American Library Association.

Elliott, R., \& Timulak, L. (2005). Descriptive and Interpretive Approaches to Qualitative Research. In J. Miles, \& P. Gilbert, A Handbook of Research Methods for Clinical and Health Psychology (pp. 147-159). Oxford: Oxford University Pres.

Fialkoff, F. (2007). The Image Thing. Library Journal 132.2, 8.

Flick, U. (2013). The SAGE Handbook of Qualitative Data Analysis. London: Sage.

Keer, G., \& Carlos, A. (2014). The Stereotype Stereotype: Our Obsession with Librarian. In N. Pagowsky, M. Rigby, \& ed., The Librarian Stereotype: Deconstructing Perceptions and Presentations of Information Work (pp. 63-84). Chicago: Association of College and Research Libraries A division of the American Library Association.

Keer, G., \& Carlos, A. (2015, October 30). The Stereotype Stereotype Our obsession with librarian representation. Retrieved from American Libraries: https://americanlibrariesmagazine.org/2015/10/30/the-stereotype-stereotype/

Keller, K. L. (2013). Strategic Brand Management Building, Measuring, and Managing Brand Equity Global Edition. Boston: Pearson.

Kneale, R. (2002). Librarian Image Study. Marketing Library Services (MLS) Volume 16, Number 8 , November/December, 3 .

Kneale, R. A. (2004, June Paper in Special Library Association). Where's the Librarian? Patron's views of public perception in the Internet age. Retrieved from Librarian Image: http://www.librarian-image.net/wheres_the_librarian.html

LIU, S., \& Tang, E. (2009). Factors Influencing Effective Rebranding Strategy . ANZMAC 2009 (pp. 1-8). Adelaide: Australian \& New Zeland Marketing Academy. 
Muzellec, L., \& Lambkin, M. (2006). Corporate rebranding: Destroying, transferring or creating brand equity? European Journal of Marketing 40(7/8):803-824 - July, 803-824.

Ozaki, S. (2006). Excitement or sophistication? A Preliminary Exploration of Online Brand Personality. International Marketing Review Vol 23, Issue 3 , 279-303.

Pagowsky, N., \& Rigby, M. (2014). Contextualizing Ourselves: The Identity Politics of the Librarian. In N. Pagowsky, M. Rigby, \& Ed., The Librarian Stereotype : Deconstructing Perceptions and Presentations of Information Work (pp. 1-38). Chicago: The Association of College \& Research Libraries, a division of the American Library Association.

Plummer, J. T. (2000). How Personality Makes a Different . Journal of Advertising Research Vol. 40 , Issue 6, 79-83.

Riggins, A. L. (2007). Review of the book The image of librarians in cinema, 1917-1999. Film International, 5 (3), 79-81.

Ryan, P., Moroney, M., Geoghegan, W., \& Cunningham. (2007). A Framework for a Strategic Repositioning Strategy: A Case. Irish Journal Of Management, 28(1), 81-102.

Steiner, S. K., \& Jones, J. (2014). Academic Librarian Self-Image in Lore: How Shared Stories Convey and Define our Sense of Professional Identity. In N. Pagowsky, M. Rigby, \& Ed., The Librarian Stereotype: Deconstructing Perceptions and Presentations of Information Work (pp. 39-62). Chicago: The Association of College \& Research Libraries, a division of.

Stuart, H. (2003). Corporate Rebranding: Issues and Implications. ANZMAC 2003 Conference Proceedings (pp. 172-178). Adelaide: Australian \& New Zeland Marketing Academy.

Sweeny, J. C., \& Brandon, C. (2006). Brand Personality : Exploring the Potential to Move from Factor Analytical to Circumplex Models. Psychology \& Marketing Vol. 23 Issue 8 , 639663.

Tevis, R., \& Tevis, B. (2005). The Image of Librarians in Cinema, 1917-1999 1st Ed. Edition. North Carolina: McFarland \& Company, Inc., Publishers.

Tjahjono, T. (2016, June 23). 6 Alternatif Ojek Online Selain GO-JEK, Grab dan Uber Bagi Para Wanita Karir. Retrieved from uprint.id Treasure What Matters: https://uprint.id/blog/alternatif-ojek-online-selain-gojek-grab-dan-uber-bagi-para-wanitakarir/

Todor, R.-D. (2014). The Importance of Branding and Rebranding for Strategic Marketing. Bulletin of the Transilvania University of Braşov Series V: Economic Sciences • Vol. 7 (56) No. 2 , 59-64.

Turner, C. (2003). Issues and Challenges in Strategic Repositioning: The Case of Cable and Wireless. Strategic Change, Vol. 12, 251-257.

Wolff, J. (2012). Marketing for Entrepreneurs. UK: Pearson. 